\title{
Split nitrogen application in potato: effects on accumulation of nitrogen and dry matter in the crop and on the soil nitrogen budget
}

\author{
J. VOS \\ Department of Crop Science, Wageningen Agricultural University, Haarweg 333, 6709 RZ Wageningen, \\ The Netherlands
}

(Revised MS received 20 May 1999)

\begin{abstract}
SUMMARY
In four field experiments, the effects of single nitrogen $(\mathrm{N})$ applications at planting on yield and nitrogen uptake of potato (Solanum tuberosum L.) was compared with two or three split applications. The total amount of $\mathrm{N}$ applied was an experimental factor in three of the experiments. In two experiments, sequential observations were made during the growing season. Generally, splitting applications (up to 58 days after emergence) did not affect dry matter (DM) yield at maturity and tended to result in slightly lower DM concentration of tubers, whereas it slightly improved the utilization of nitrogen. Maximum haulm dry weight and $N$ content were lower when less nitrogen was applied during the first 50 days after emergence (DAE). The crops absorbed little extra nitrogen after 60 DAE (except when three applications were given). Soil mineral N $(0-60 \mathrm{~cm})$ during the first month reflected the pattern of $\mathrm{N}$ application with values up to $27 \mathrm{~g} / \mathrm{m}^{2} \mathrm{~N}$. After $60 \mathrm{DAE}$, soil mineral $\mathrm{N}$ was always around $2-5 \mathrm{~g} / \mathrm{m}^{2}$. The efficiency of $\mathrm{N}$ utilization, i.e. the ratio of the $\mathrm{N}$ content of the crop to total $\mathrm{N}$ available (initial soil mineral $\mathrm{N}+$ deposition + net mineralization) was 0.45 for unfertilized controls. The utilization of fertilizer $\mathrm{N}$ (i.e. the apparent $\mathrm{N}$ recovery) was generally somewhat improved by split applications, but declined with the total amount of $\mathrm{N}$ applied (range $0 \cdot 48-0 \cdot 72$ ). $\mathrm{N}$ utilization and its complement, possible $\mathrm{N}$ loss, were similar for both experiments with sequential observations. Separate analysis of the movement of $\mathrm{Br}^{-}$indicated that some nitrate can be washed below $60 \mathrm{~cm}$ soil depth due to dispersion during rainfall. The current study showed that the time when $\mathrm{N}$ application can be adjusted to meet estimated requirements extends to (at least) 60 days after emergence. That period of time can be exploited to match the $\mathrm{N}$ application to the actual crop requirement as it changes during that period.
\end{abstract}

\section{INTRODUCTION}

The nitrogen $(\mathrm{N})$ requirement of a potato crop can initially be met from nitrogen already present in the soil at planting (soil mineral $\mathrm{N}$ ), plus nitrogen made available by transformation processes in the soil plus atmospheric deposition plus microbial processes fixing atmospheric N. However, the supply of these processes is normally too small to sustain unrestricted growth and the grower needs to supplement the supply with fertilizer or manures. It is the aim of the grower to provide sufficient nitrogen to achieve the optimum possible yield for the particular environmental conditions and genotype. The following

Email: jan.vos@users.agro.wau.nl formulae provide a quantitative description of the seasonal $\mathrm{N}$ requirement:

$$
\mathrm{N}_{\mathrm{r}}=(Y * f)-\left(\mathrm{N}_{\mathrm{i}}+\mathrm{N}_{\mathrm{n}}+\mathrm{N}_{\mathrm{d}}\right) * e_{\mathrm{s}}
$$

and

$$
\mathrm{N}_{\mathrm{a}}=\mathrm{N}_{\mathrm{r}} / e_{\mathrm{a}}
$$

where $\mathrm{N}_{\mathrm{r}}=$ the amount of nitrogen that the crop needs to take up from external input $\left(\mathrm{g} / \mathrm{m}^{2}\right), Y=$ total crop yield $\left(\mathrm{g} / \mathrm{m}^{2}\right), f=$ the fraction of nitrogen in crop dry matter, $\mathrm{N}_{\mathrm{i}}=$ soil mineral $\mathrm{N}$ present at planting $\left(\mathrm{g} / \mathrm{m}^{2}\right), \mathrm{N}_{\mathrm{n}}=$ net $\mathrm{N}$ mineralization during the growing season, $\mathrm{N}_{\mathrm{d}}=$ atmospheric deposition and fixation during the growing season $\left(\mathrm{g} / \mathrm{m}^{2}\right), \mathrm{N}_{\mathrm{a}}=$ $\mathrm{N}$ to apply with fertilizer or manures $\left(\mathrm{g} / \mathrm{m}^{2}\right), e_{\mathrm{s}}=$ the efficiency of utilization of nitrogen from all sources other than externally supplied as fertilizer or manure; efficiency of utilization is here the fraction of available 
$\mathrm{N}$ absorbed by the crop, and $e_{\mathrm{a}}=$ the efficiency of utilization of applied (fertilizer) $\mathrm{N}$.

The coefficient $e_{\mathrm{a}}$ is equivalent to the apparent fertilizer nitrogen recovery, ANR, commonly defined by:

$$
\operatorname{ANR}=\left(\mathrm{N}_{\mathrm{f}}-\mathrm{N}_{0}\right) / \mathrm{N}_{\mathrm{a}} \quad \text { (fraction) }
$$

where $\mathrm{N}_{\mathrm{f}}=$ the nitrogen content at harvest of a fertilized crop $\left(\mathrm{g} / \mathrm{m}^{2}\right), \mathrm{N}_{0}=$ the nitrogen content of a zero-N control $\left(\mathrm{g} / \mathrm{m}^{2}\right)$.

With a single nitrogen application at the beginning of the growing season it is virtually impossible to get the calculation of $\mathrm{N}_{\mathrm{a}}$ right because $Y$ cannot be predicted in advance. $Y$, and perhaps also $f$, depends on future weather and on biotic and abiotic stress factors present in the field. The magnitude of seasonal variation in $Y$ is indicated by Haverkort \& van de Waart (1994), who described 13 field experiments, conducted on different sites from 1982 to 1989, and showed that tuber dry matter (DM) of cv. Astarte varied from 1000 to $1700 \mathrm{~g} / \mathrm{m}^{2}$ for rates of $\mathrm{N}$ applied prior to planting ranging from 24 to $30 \mathrm{~g} / \mathrm{m}^{2}$. Since there was no systematic effect of $\mathrm{N}$ rate on yield, the variation in yield was ascribed to seasonal factors such as periods of drought or excessive rainfall, varying temperature and frost damage. Vos (1996) reported comparable variation in yield, while $\mathrm{N}$ offtake varied from 15 to $27 \mathrm{~g} / \mathrm{m}^{2}$ (four seasons, several rotations, $23 \mathrm{~g} / \mathrm{m}^{2} \mathrm{~N}$ applied in a single application).

The rate of net mineralization depends on the $\mathrm{C}: \mathrm{N}$ ratio of active organic pools and on soil temperature and soil moisture which can vary between and within seasons. Therefore, the contribution of net mineralization to the seasonal $\mathrm{N}$ budget is difficult to predict in advance. The efficiency of utilization of nitrogen is certainly $<1$, but is variable since it is affected by events such as immobilization, leaching and denitrification.

With one application in spring only, the grower is tempted to apply a high $\mathrm{N}$ rate because (i) he/she wants to avoid the risk of $\mathrm{N}$ deficiency under favourable growing conditions and (ii) there is little or no yield penalty associated with overdressing $\mathrm{N}$ (Neeteson 1989; Vos 1997). However, if the yield falls below the potential level due to stresses, the crop cannot utilize all available $\mathrm{N}$ and excess nitrogen is at risk of being transmitted to the environment. This is not acceptable because crop nutrition strategies need to minimize loss to the environment.

Theoretically, with split nitrogen applications, the prospects of 'getting the calculation right' increase. The grower divides the total growing period into shorter time periods. Therefore, the time horizon of a decision is much shorter than a whole growing season as is the case with a single application at planting. At the beginning of each period a decision is taken on how much nitrogen is required until the next decision or until the final harvest, taking into account the current state of the crop and any effects of stresses that the crop may have suffered from until the point of decision. Sufficient nitrogen needs to be available during each of these periods. With moderate applications in the seedbed and later supplements, the risk is reduced of losing $\mathrm{N}$ during the first 4-6 weeks after planting when there is no or little uptake of $\mathrm{N}$.

The available literature indicates that in temperate climates potato yield is generally at least as high with split applications than with a single application at planting (Bachthaler et al. 1973; Westermann et al. 1988; Porter \& Sisson 1993). As is outlined, maximizing the utilization of applied $\mathrm{N}$ rather than yield improvement is the prime incentive for splitting $\mathrm{N}$. However, little work is done to define the window of opportunity to dynamically adjust $\mathrm{N}$ application to the crop's need. This paper primarily deals with the question of the time span during which the potato crop can respond positively and efficiently to additional nitrogen in the absence of other stresses. Another aspect is the extent to which a crop can recover from temporary $\mathrm{N}$ deficiency. The last objective of the paper is to analyse the nitrogen budget of the soil and quantify the effect of split $\mathrm{N}$ application on the potential nitrogen losses and the efficiency of nitrogen utilization.

\section{MATERIALS AND METHODS}

\section{Details of the experiments}

Four experiments (Expt 1-4) were conducted between 1989 and 1993 (Table 1) on sandy soils near Wageningen, $\mathrm{NL}, 52^{\circ} \mathrm{N}$. The cultivars Prominent and Vebeca are both starch potato cultivars of similar maturity class ( $4 \cdot 5$ in the Dutch List of Recommended Cultivars). All relevant standard cultural measures were taken to ensure unrestricted growth. The distance between rows was $0.75 \mathrm{~m}$, and in each row the plants were spaced at $33 \mathrm{~cm}$ (i.e. 4 plants $/ \mathrm{m}^{2}$ ). Plots were $4.5 \mathrm{~m}$ wide (6 rows) and $6 \mathrm{~m}$ long. Irrigation was applied as necessary to avoid water shortage. Evapotranspiration from April 20 to September was calculated as c. $330-400 \mathrm{~mm}$. On a seasonal basis, water supply exceeded water requirement. Crops were generally free from weeds and diseases. A completely randomized block design with five blocks was used in most experiments (four blocks in Expt 3).

Treatments consisted of a zero nitrogen control, several rates of nitrogen supply (Table 1) in factorial combination with the number of splits, i.e. one application near planting versus two or three splits of $50 \%$ or $33 \%$ of the total at each application date (Table 1).

In Expt 4 treatments consisted of doses of $20 \mathrm{~g} / \mathrm{m}^{2}$ with one, two and three splits plus a treatment with delay of the $20 \mathrm{~g} / \mathrm{m}^{2}$ dose until the second date of application. A treatment with $30 \mathrm{~g} / \mathrm{m}^{2}(25+5)$ served as a high $\mathrm{N}$ control. 
Table 1. Details of the experiments

\begin{tabular}{|c|c|c|c|c|}
\hline Variable & Expt 1 & Expt 2 & Expt 3 & Expt 4 \\
\hline Cultivar & Prominent & Prominent & Vebeca & Vebeca \\
\hline \multicolumn{5}{|l|}{ Inorganic $\mathrm{N}$ spring: } \\
\hline $0-30 \mathrm{~cm}\left(\mathrm{~g} / \mathrm{m}^{2}\right)$ & $3 \cdot 2$ & $2 \cdot 8$ & $4 \cdot 5$ & $2 \cdot 9$ \\
\hline $30-60 \mathrm{~cm}\left(\mathrm{~g} / \mathrm{m}^{2}\right)$ & $1 \cdot 6$ & 1.9 & $2 \cdot 1$ & $1 \cdot 5$ \\
\hline Planting date & 17 April 1989 & 18 April 1990 & 21 April 1992 & 22 April 1993 \\
\hline $\mathrm{N}$ rates $\left(\mathrm{g} / \mathrm{m}^{2}\right)$ & $0,15,20,25$ & $0,10,20,30$ & $0,11,18,25$ & $0,20,30^{*}$ \\
\hline \multicolumn{5}{|l|}{ Application date of: } \\
\hline 1 st dose of $N$ fertilizer & 12 April & 23 April & 11 May & 26 April \\
\hline 2nd dose $\dagger$ & 27 June & 28 June & 17 June & 10 June \\
\hline $3 \mathrm{rd}$ dose $\dagger$ & - & - & 13 July & 6 July \\
\hline Date of $50 \%$ emergence & 17 May & 9 May & 16 May & 12 May \\
\hline \multicolumn{5}{|l|}{ Rainfall + irrigation } \\
\hline 20 April-September (mm) & 388 & 478 & 487 & 449 \\
\hline Harvest date & Sept 18 -Oct $13 \%$ & Sept $10-30 \$$ & Sept 21 & Sept 22 \\
\hline Below ground parts & Excluded & Excluded & Included & Included \\
\hline Number of plants per sample & 60 & 60 & 30 & 36 \\
\hline $\begin{array}{l}\text { N-uptake by zero-N-controls at } \\
\text { harvest }\left(\mathrm{g} / \mathrm{m}^{2}\right)\end{array}$ & $6 \cdot 1$ & $5 \cdot 7$ & $7 \cdot 2$ & $5 \cdot 5$ \\
\hline Number of sequential harvests & 1 & 1 & 4 & 5 \\
\hline
\end{tabular}

* Only four $20 \mathrm{~g} / \mathrm{m}^{2} \mathrm{~N}$ treatments with 1,2 , and 3 applications were included, plus treatment $0+20 \mathrm{~g} / \mathrm{m}^{2}$ (delay in first application and $20 \mathrm{~g} / \mathrm{m}^{2}$ on the second application date) and treatment $25+5=30 \mathrm{~g} / \mathrm{m}^{2}$ (i.e. 25 and $5 \mathrm{~g} / \mathrm{m}^{2} \mathrm{~N}$ on the first and second dates of applications, respectively; regarded as supra-optimal control).

$\dagger$ When the total application was split, $50 \%$ of the total was applied per application with two applications, and $33 \%$ per application with three applications.

\$. Each treatment was harvested when soil cover had dropped below c. $20 \%$.

The officially recommended rate equals $27.5 \mathrm{~g} / \mathrm{m}^{2}$ $\mathrm{N}$ minus 1.8 times the amount of mineral $\mathrm{N}$ in the $0-30 \mathrm{~cm}$ layer in spring. For the current site the recommended rate was 18 and $20 \mathrm{~g} / \mathrm{m}^{2}$ in Expt 3 and Expt 4, respectively. Rates lower than the recommended rate were included to demonstrate whether improved efficiency of utilization would occur with split dressings. High $\mathrm{N}$ controls $\left(25-30 \mathrm{~g} / \mathrm{m}^{2}\right)$ were included to check that the standard rates were near the optimum for unrestricted growth. Nitrogen was always applied as calcium ammonium nitrate (equal parts of ammonium and nitrate). First applications were prior to or just after planting (see dates in Table 1). Second and third applications were broadcast over the crop and, unless rainfall was expected, followed by $15 \mathrm{~mm}$ irrigation (because it was the objective of the study to analyse the effect of splitting $\mathrm{N}$ on the crop and not the interaction between splitting $\mathrm{N}$ and water supply).

\section{Observations and calculations}

Samples of plants were taken from two adjacent rows in the centre of the plots. Plants were dissected into three parts: haulms (stems plus leaves, cut at soil surface), tubers, and 'other underground plant parts' which were recovered when digging the potatoes (underground stem parts, stolons, some of the roots). Fresh and dry weights were determined of each plant part. Subsequently samples were ground and nitrogen concentrations in the DM were determined. Crops were sampled at maturity only in Expts 1 and 2, four times in Expt 3 and five times in Expt 4.

At each sampling, the degree of branching was recorded on all of five stems per plot (only in Expt 4). The cultivars used are indeterminate, producing various orders of apical lateral branches (Vos 1999). The main stem and each apical branch terminate in an inflorescence. The first order of apical branches emerges from the axil of the second and third leaf below the inflorescence on the main stem. The first order of apical branches produces the second order of apical branches from comparable leaf positions as on the main stem. Hence, the first, second and third order of apical branches consist of two, four and eight stem segments. The degree of branching was expressed as the frequency $(\%)$ of occurrence of each order of branches, i.e. the number of segments counted on five plants as a percentage of the maximum number possible. A branch was counted as appeared when clearly distinguishable, regardless of the number of expanded leaves. Other variables characterizing the development of the foliage were the frequency of basal lateral branches and the fraction of haulm DM present in basal lateral branches (Expt 4).

Near planting, and at each sampling date, soil samples were taken from the $0-30$ and $30-60 \mathrm{~cm}$ layers to determine the mineral nitrogen content 
(nitrate plus ammonium). Six subsamples were taken across the plot and pooled. During the growing season of 1993 (Expt 4) and in autumn after harvest, measurements were made of the in situ rate of mineralization (Raison et al. 1987), using 40-cm long plastic cylinders with a diameter of $7 \mathrm{~cm}$ which were placed in the soil with their tops level with the soil surface. The cylinders were closed with a lid to prevent the entry of rain. Six tubes were placed diagonally across the plot. The top $30 \mathrm{~cm}$ of soil adjacent to the tubes was sampled and provided an estimate of the initial amount of mineral N. At the end of the incubation period the top $30 \mathrm{~cm}$ of soil in the cylinder itself was sampled and analysed for $\mathrm{N}_{\min }$. The difference between the initial and final value of $\mathrm{N}_{\text {min }}$ provided an estimate of the net mineralization over the period concerned. In some treatments of Expt 4 a surface area of $8 \mathrm{~m}^{2}$ was covered with black, impermeable polythene film on 24 September ( 2 days after harvest). The film prevented the downward movement of nitrate. The difference in initial $\mathrm{N}_{\text {min }}$ and $\mathrm{N}_{\min }$ on 14 December provided an estimate of net mineralization in the autumn period after harvest.

Rainfall was recorded on the site. Precipitation surpluses and deficits $(\mathrm{mm})$ were calculated as the difference between (rainfall + irrigation) - calculated evapotranspiration. The units of time were three periods per month, i.e. days $1-10,11-20$ and days $21-30$ or 31 . These periods will be called, for instance, April I, II and III. Calculated evapotranspiration was obtained by multiplying the reference evapotranspiration, provided by the Royal Meteorological Institute (KNMI) at De Bilt, by a relevant crop factor (Feddes 1987).

For an approximation of nitrate leaching, the movement of $\mathrm{Br}^{-}$to depth in the soil profile was studied in the period September 1995 to March 1996 (De Smedt et al. 1986). On 14 September $58 \mathrm{~g} / \mathrm{m}^{2} \mathrm{Br}^{-}$ was applied as $\mathrm{KBr}$; that amount of $\mathrm{Br}$ is equivalent to $10 \mathrm{~g} / \mathrm{m}^{2} \mathrm{~N}$ as nitrate. From 5 days after the $\mathrm{KBr}$ application, samples were taken on ten dates till $80 \mathrm{~cm}$ depth with increments of $20 \mathrm{~cm}$. Soil moisture contents and $\mathrm{Br}^{-}$concentrations were determined. $\mathrm{Br}^{-}$movement was measured during autumn and winter because there is a continuous precipitation surplus during these seasons.

\section{Methods of chemical analysis}

First the plant material was digested with sulphuric acid using salicylic acid, $\mathrm{H}_{2} \mathrm{O}_{2}$ and selenium as additives (Novozamsky et al. 1983). Nitrogen was determined by colorimetry in an auto-analyser using the Berthelot reaction (Novozamsky et al. 1974). Soil mineral nitrogen was determined using standard techniques (Houba et al. 1986); mineral nitrogen is defined as the sum of extracted ammonium and nitrate.

\section{RESULTS}

\section{Harvest at maturity}

Yield generally increased with nitrogen application rate. Yield responses to nitrogen in these experiments, except for treatments with three applications, were reported by Vos (1997). Splitting the dose into two or three applications did not significantly affect total crop DM at maturity in any of the experiments. Splitting the $\mathrm{N}$ dose had no significant effects on tuber dry yield, except in Expt 1, where averaged over $\mathrm{N}$ rates, $1292 \mathrm{~g} / \mathrm{m}^{2}$ tuber DM was produced with one application in spring $v .1205 \mathrm{~g} / \mathrm{m}^{2}$ with two dressings. Splitting the $\mathrm{N}$ dose lowered the dry matter concentration in tubers (DMCT) in Expts 1 and 3, and had no effect in Expt 4 (data on fresh tuber weight from Expt 2 were lost). In Expt 1 DMCT was not affected at the $\mathrm{N}$ rate of $15 \mathrm{~g} / \mathrm{m}^{2}$, but declined by splitting the dose from $247 \mathrm{~g} / \mathrm{kg}$ to $235 \mathrm{~g} / \mathrm{kg}$ for $\mathrm{N}$ rates of 20 and $25 \mathrm{~g} / \mathrm{m}^{2}$. Averaged over $\mathrm{N}$ rates, DMCT declined from $261 \mathrm{~g} / \mathrm{kg}$ for a single application to 258 and $254 \mathrm{~g} / \mathrm{kg}$ for two and three applications, respectively. The $\mathrm{N}$ content of the total crop and of tubers was not affected in Expts 1 and 4. However, in Expts 2 and 3 both variables showed $c$. $10 \%$ higher values with two and three applications than with a single application. Therefore, splitting the dose did not affect DM yield at maturity (with one exception with a negative effect) and tended to result in slightly lower DMCT, whereas it slightly improved utilization of nitrogen.

Changes during the season in the accumulation of dry matter and nitrogen

Figures $1 a-f$ and $2 a-f$ show the changes during the season of the dry weight and $\mathrm{N}$ content of haulms, tubers and total crop for Expt 3 (focusing on treatments with $18 \mathrm{~g} / \mathrm{m}^{2} \mathrm{~N}$ applied in total) and Expt 4 (all treatments). Important aspects are:

(i) Applying more $\mathrm{N}$ than the standard rates of 18 and $20 \mathrm{~g} / \mathrm{m}^{2}$ had only marginal and non-significant positive effects on final yield.

(ii) The change with time in tuber dry weight and its $\mathrm{N}$ content varied little between treatments.

(iii) Postponement of the $\mathrm{N}$ application of $20 \mathrm{~g} / \mathrm{m}^{2}$ to 10 June (29 days after emergence, DAE) had no effect on final yield and $\mathrm{N}$ uptake in Expt 4 (treatment $\mathrm{N} 0+20$ ).

(iv) The most obvious effects of the treatments were on the dry weight of haulms and even more on the nitrogen content of the haulms. On the first sampling date, i.e. 28 DAE in Expt 3 and 27 DAE in Expt 4, haulm dry weight and haulm $\mathrm{N}$ content increased with increase in amount of $\mathrm{N}$ applied near planting; the responses were stronger in Expt 3 than in Expt 4 which may be related to the fact that the crop mass was bigger on 28 DAE in Expt 3 than on 

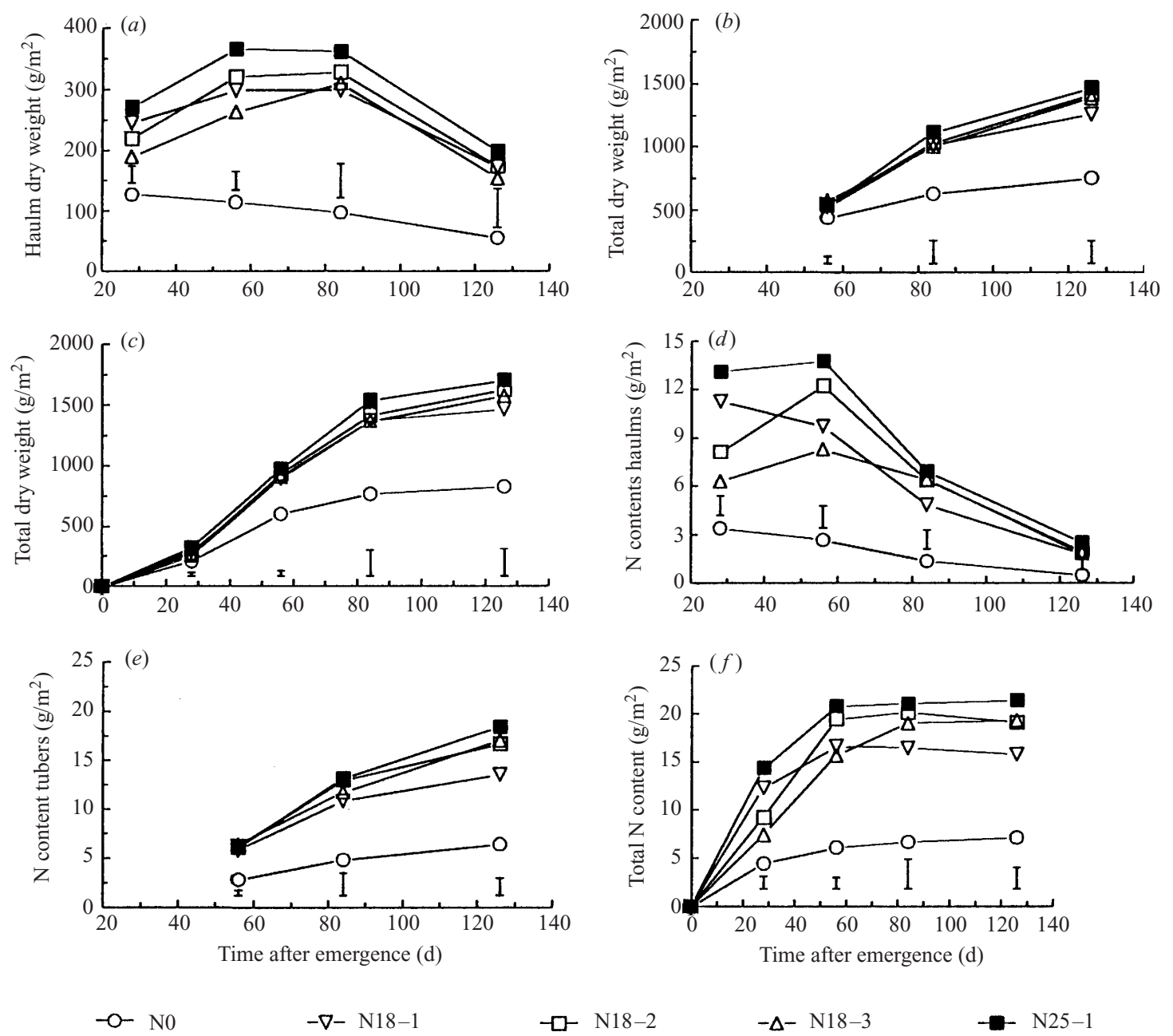

$-\nabla-\mathrm{N} 18-1$

-마 N18-2

$-\Delta-\mathrm{N} 18-3$

$\mathrm{N} 25-1$

Fig. 1. Summary of changes with time in crop attributes in Expt $3 ;(a)$ haulm dry matter, $(b)$ tuber dry matter, $(c)$ total dry matter, $(d) \mathrm{N}$ content of haulms, $(e) \mathrm{N}$ content of tubers, $(f) \mathrm{N}$ content of total crop. The error bar shows the Least Significant Difference, L.S.D. $(P=0 \cdot 05 ; 24$ degrees of freedom, D.F., of error). Treatment codes: N0: zero-N control; N18-3, for instance, means total supply of $18 \mathrm{~g} / \mathrm{m}^{2}$, applied in three equal doses.

27 DAE in Expt 4. Particularly with three applications, the peak in dry weight and $\mathrm{N}$ content of haulms was lower than in the other treatments and occurred later in time for haulm dry weight. The following comparison underlines the large effect of splitting the $\mathrm{N}$ dose on the pattern of change in time of haulm variables: on 28 DAE in Expt 3 haulm dry weight and $\mathrm{N}$ content were 246 and $11 \cdot 3 \mathrm{~g} / \mathrm{m}^{2}$ with a single application $\left(\mathrm{N}\right.$ rate $\left.18 \mathrm{~g} / \mathrm{m}^{2}\right)$ and 190 and $6.3 \mathrm{~g} / \mathrm{m}^{2}$ in the treatment with three applications. Still, final yield and $\mathrm{N}$ uptake were at least as high with three applications than with one application.

(v) Total DM accumulation continued throughout the season, although little gain was achieved after $c$. 100 DAE. Total N content showed little change after c. 60 DAE, except for treatments with three applications in which total $\mathrm{N}$ content increased until $c .80$ DAE. These data imply that about half of the final total DM of the crop was produced by diluting the nitrogen already present in the crop.

\section{Development of the foliage (Expt 4)}

The frequency of presence of the first order apical branches (Fig. 3) did not show significant differences between treatments throughout the total period of observation, although both treatments without fertilizer applied at planting ( $\mathrm{N} 0$ and $\mathrm{N} 0+20)$ showed the lowest frequencies on $28 \mathrm{DAE}$. The second and third order branches started to appear at a similar time in 

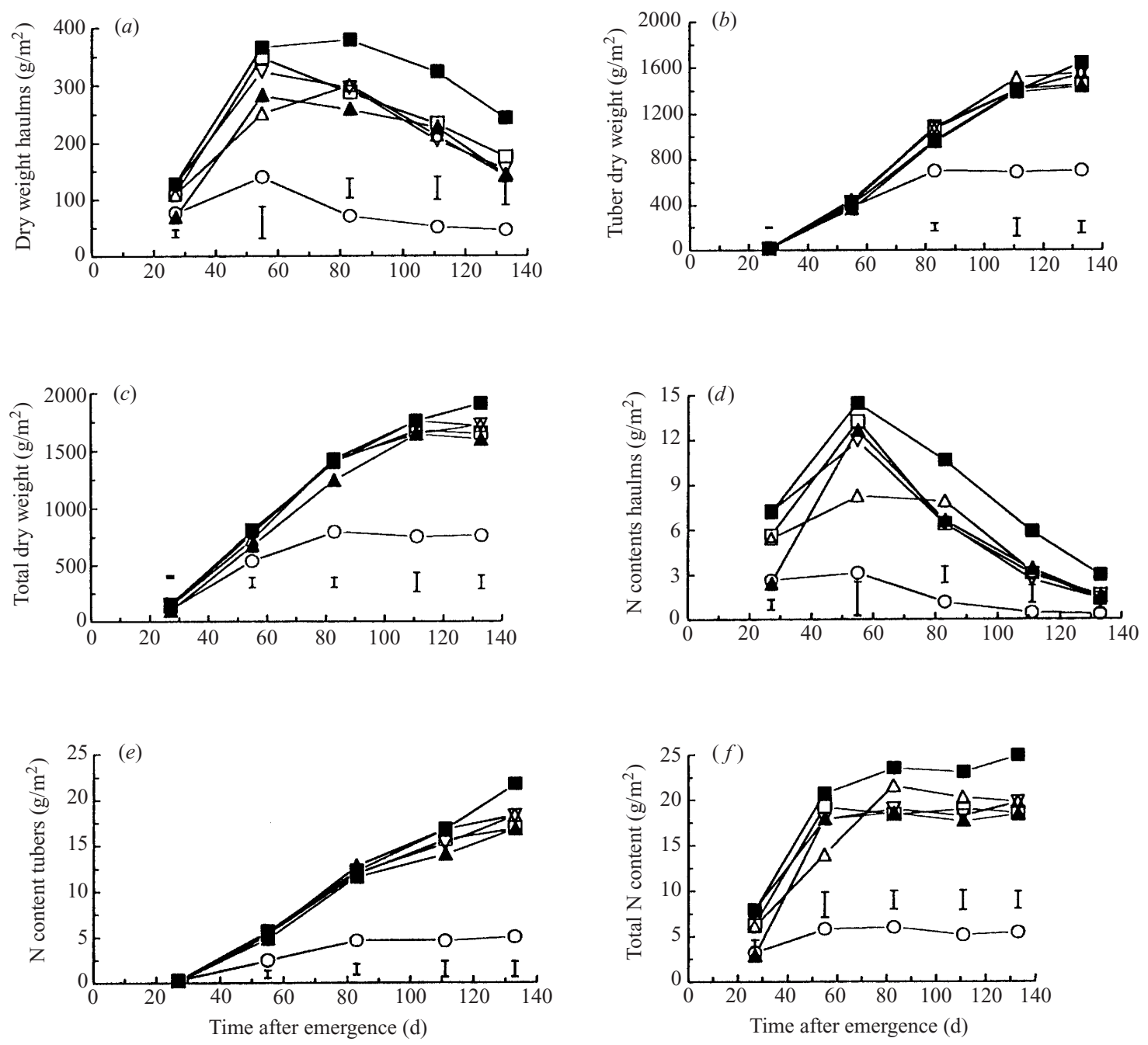

$-\mathrm{O}$ N0

$-\nabla-\quad N 20-1$

마 N20-2

$-\Delta-\mathrm{N} 20-3$

-A- $\mathrm{N} 0+20$

$\mathrm{N} 25+5$

Fig. 2. Summary of changes with time in crop attributes in Expt $4 ;(a)$ haulm dry matter, $(b)$ tuber dry matter, $(c)$ total dry matter, $(d) \mathrm{N}$ content of haulms, $(e) \mathrm{N}$ content of tubers, $(f) \mathrm{N}$ content of total crop. The error bar shows the least Significant Difference, L.S.D. $\left(P=0 \cdot 05 ; 20\right.$ D.F. error). Treatment codes: N20-3, for instance, means total supply of $20 \mathrm{~g} / \mathrm{m}^{2}$, applied in three equal doses; the code $\mathrm{N} 0+20$ designates the treatment where the total dose of $20 \mathrm{~g} / \mathrm{m}^{2}$ was applied on the second date of application (Table 1); the code $\mathrm{N} 25+5$ represents 'a high $\mathrm{N}$ control' given $20 \mathrm{~g} / \mathrm{m}^{2}$ on the first date of application and $5 \mathrm{~g} / \mathrm{m}^{2}$ on the second date.

all treatments. However, in the N0 treatment the frequency of the second order branches was maximally $4 \%$, while third order branches did not appear at all. On 56 and 84 DAE, significantly more second order branches were found in treatment $\mathrm{N} 25+5$ than in the treatments with $20 \mathrm{~g} / \mathrm{m}^{2}$; likewise more third order branches were found on 84 and 112 DAE. The amount of $\mathrm{N}$ applied determined the final degree of apical branching, but within treatments with $20 \mathrm{~g} / \mathrm{m}^{2}$
$\mathrm{N}$ applied, the final degree of development of the foliage was not modified by the distribution of $\mathrm{N}$ application in time.

On 84 DAE, the number of basal lateral branches per main stem was 0.5 in N0, $1.3-1.5$ in treatments with $20 \mathrm{~g} / \mathrm{m}^{2} \mathrm{~N}$ applied and $2 \cdot 0$ in $\mathrm{N} 25+5$. The fraction of haulm dry matter present in basal branches was $0 \cdot 14$ in N0, $0 \cdot 21-0 \cdot 26$ in treatments with $20 \mathrm{~g} / \mathrm{m}^{2}$ $\mathrm{N}$ applied and 0.3 in treatment $\mathrm{N} 25+5$ (differences 
Frequency of branch order (\%)

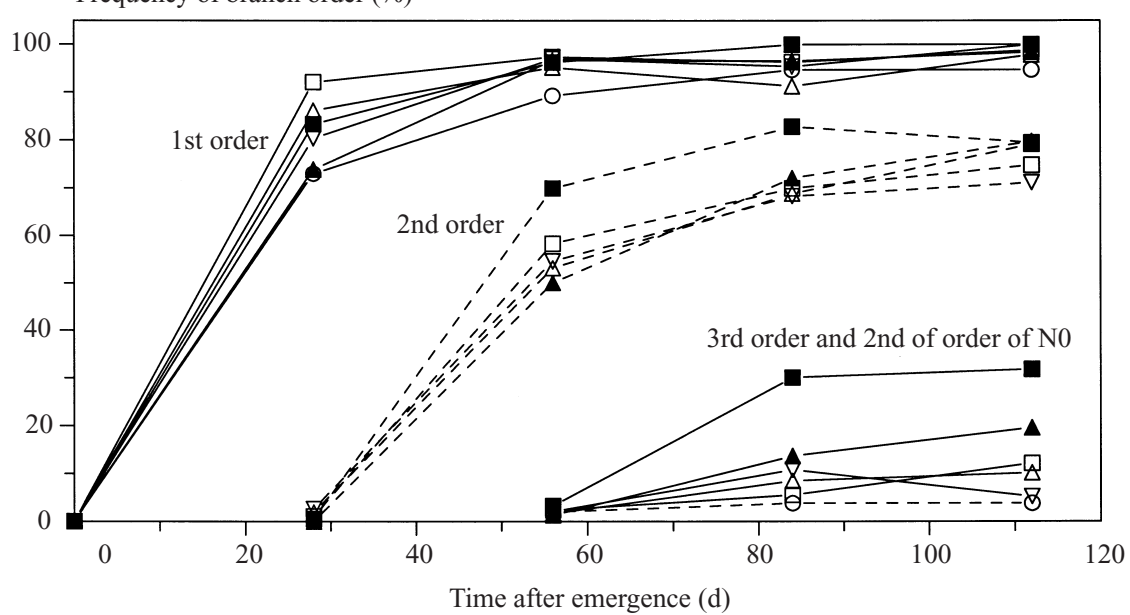

Fig. 3. Frequency of presence (\%) of various orders of apical lateral branches (Expt 4). The second order branches are represented by broken lines, see legend to Fig. 2 for treatment codes.

between $\mathrm{N} 0$ and $\mathrm{N} 25+5$ always statistically significant both for number and weight fraction of basal branches). Differences between treatments in these variables were due to different amount rather than different timing of $\mathrm{N}$ application.

\section{Changes in soil mineral nitrogen in the top $0-60 \mathrm{~cm}$ (Expts 3 and 4)}

Soil mineral $\mathrm{N}$ in the top $60 \mathrm{~cm}$ of the soil before planting in spring was c. $6.6 \mathrm{~g} / \mathrm{m}^{2}$ in Expt 3 (Fig. $4 a$ ) and $4.4 \mathrm{~g} / \mathrm{m}^{2}$ in Expt 4 (Fig. $4 b$ ). On 28 DAE in Expt 3 and 27 DAE in Expt 4 soil mineral $\mathrm{N}$ was higher with increase in amount of $\mathrm{N}$ applied at the first application near planting. Peak values of 25 and $27 \mathrm{~g} / \mathrm{m}^{2}$ were found in the treatments of Expt 4 with an initial rate of 20 and $25 \mathrm{~g} / \mathrm{m}^{2} \mathrm{~N}$, respectively. From $c .60 \mathrm{DAE}$ onwards soil mineral $\mathrm{N}$ values were low $\left(<5 \mathrm{~g} / \mathrm{m}^{2}\right)$ and did not differ between treatments. At harvest, the mean value across treatments was $3.5 \mathrm{~g} / \mathrm{m}^{2}$ in Expt 3 and $2.9 \mathrm{~g} / \mathrm{m}^{2}$ in Expt 4.

\section{Seasonal $N$ balance sheets}

Table 2 contains an account of the processes and variables which were considered to construct seasonal nitrogen budgets. Numerical values are given only when equal for all treatments. Sources are processes or factors making $\mathrm{N}$ available to the crop, sinks are processes tying up nitrogen, including the residual amount of soil mineral $\mathrm{N}$ at harvest. The nitrogen excess is defined as the difference between the totals of sources and sinks. An equivalent expression for the $\mathrm{N}$ excess would be the amount of $\mathrm{N}$ unaccounted for. Figure 5 shows that the $\mathrm{N}$ excess increased linearly with increase in total amount of $\mathrm{N}$ applied; data from all treatments of both experiments were fitted to a single linear regression (presented in the caption to Fig. 5). The value of the intercept, $4 \cdot 7 \mathrm{~g} / \mathrm{m}^{2}$, represents the fitted excess without adding fertilizer $\mathrm{N}$. The coefficient of the regression, $0 \cdot 35$, indicates that the $\mathrm{N}$ excess increased with $0.35 \mathrm{~g} / \mathrm{m}^{2}$ for every unit of fertilizer $\mathrm{N}$ applied. For a given total amount of $\mathrm{N}$ applied, the $\mathrm{N}$ excess decreased a little with increase in the number of fertilizer applications.

Table 2 defines the variable 'possible $\mathrm{N}$ loss'. If the $\mathrm{N}$ pools in the field are in steady state (when considered on an annual basis) then next year's net mineralization needs to be provided by the $\mathrm{N}$ excess of the current year. Therefore, subtracting mineralization from the $\mathrm{N}$ excess yields an approximation of the possible $\mathrm{N}$ loss during the growing season. For the zero-N controls the actual values were $-1.4 \mathrm{~g} / \mathrm{m}^{2}$ in Expt 3 and $-1.0 \mathrm{~g} / \mathrm{m}^{2}$ in Expt 4 ; the fitted value was $-1.6 \mathrm{~g} / \mathrm{m}^{2}$ (Fig. 5). Under the assumption that no losses occur during the growing season in treatments without an input of fertilizer $\mathrm{N}$, the intercept should be close to zero (negative values can arise from errors in estimating components of the budget, e.g. an overestimation of net mineralization and an underestimation of atmospheric deposition). As for the $\mathrm{N}$ excess, the calculated possible loss increased with $0.35 \mathrm{~g} / \mathrm{m}^{2}$ for every unit of extra input of fertilizer $\mathrm{N}$ with little effect of the number of applications, implying losses were not incurred in the period between the first application and some time after the last application.

Net mineralization in the period 24 September to 14 December was low and varied between treatments from 0.4 to $1.2 \mathrm{~g} / \mathrm{m}^{2}$ with an average value of $0.9 \mathrm{~g} / \mathrm{m}^{2}(0-60 \mathrm{~cm}$ depth $)$. This implies that little of the $\mathrm{N}$ excess returned to the pool of labile $\mathrm{N}$ in the autumn following the harvest of the crop. 

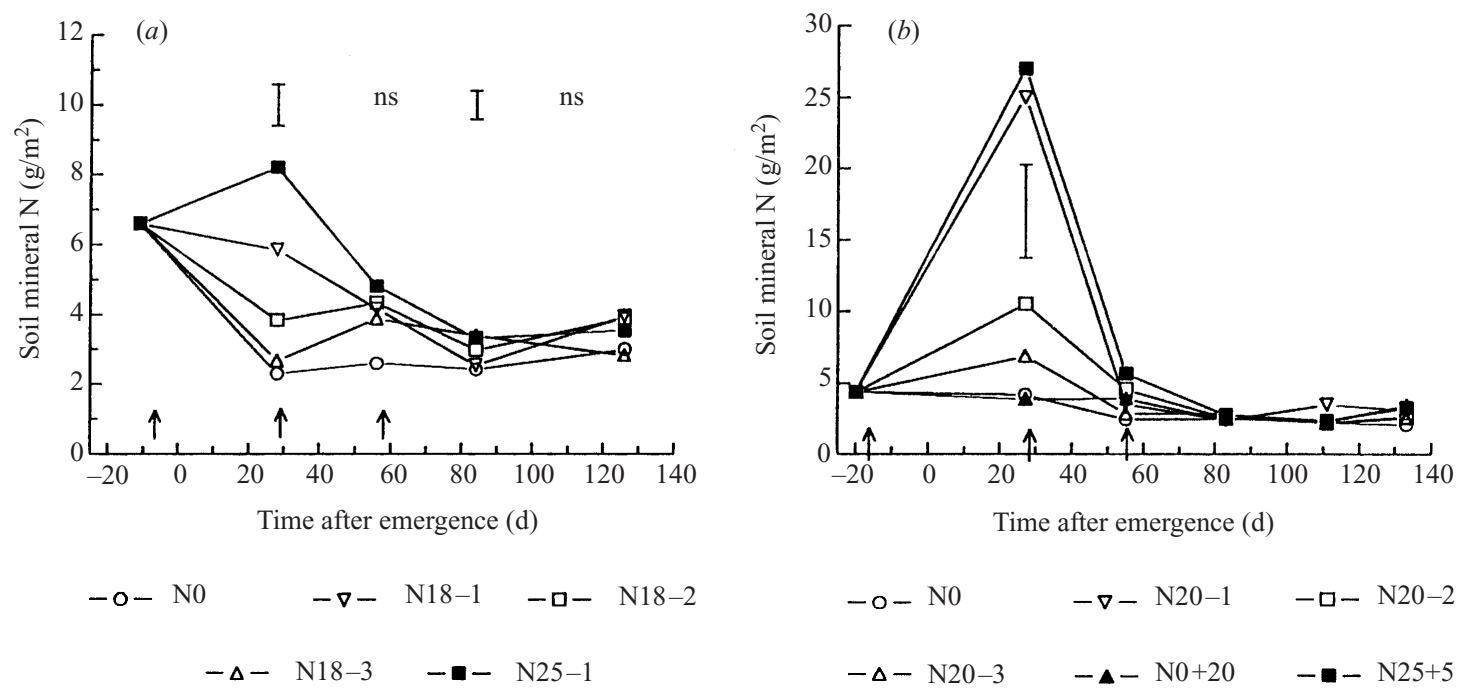

Fig. 4. Changes in soil mineral nitrogen $\left(\mathrm{g} / \mathrm{m}^{2} ; 0-60 \mathrm{~cm}\right.$ depth) Expt $3(a)$ and Expt $4(b)$. Vertical bars represent the least L.S.D. $(P=0.05), \mathrm{ns}=$ no significant differences between any of the means (D.F. error is 24 in Expt 3 and 20 in Expt 4). Arrows on the $x$ axis indicate fertilizer application dates.

Table 2. Items considered on the seasonal nitrogen balance sheets (period from planting to harvest) $\left(\mathrm{g} / \mathrm{m}^{2}\right)$

\begin{tabular}{|c|c|c|}
\hline & Expt 3 & Expt 4 \\
\hline \multicolumn{3}{|l|}{ Sources } \\
\hline$+\mathrm{Nmin}(0-60 \mathrm{~cm})$ at planting & $6 \cdot 6$ & $4 \cdot 4$ \\
\hline$+\mathrm{N}$ applied & $\mathrm{v}^{*}$ & $\mathrm{v}$ \\
\hline+ net mineralization $\dagger$ & $6 \cdot 3$ & $6 \cdot 3$ \\
\hline +atmospheric deposition: & $2 \cdot 2$ & $2 \cdot 2$ \\
\hline Total of $\mathrm{N}$ sources & $\mathrm{v}$ & $\mathrm{v}$ \\
\hline \multicolumn{3}{|l|}{ Sinks } \\
\hline$-\mathrm{N}$ content crop at harvest & $\mathrm{v}$ & $\mathrm{v}$ \\
\hline$-\mathrm{Nmin}(0-60 \mathrm{~cm})$ at harvest & $\mathrm{v}$ & $\mathrm{v}$ \\
\hline Total of $\mathrm{N}$ sinks & v & \\
\hline \multicolumn{3}{|c|}{$\begin{array}{l}\mathrm{N} \text { excess }=\text { total of } \mathrm{N} \text { sources }- \text { total of } \mathrm{N} \text { sinks. } \\
\text { Possible } \mathrm{N} \text { loss }=\mathrm{N} \text { excess }- \text { net mineralization. } \\
\text { Efficiency of utilization: } \\
\text { (i) for zero } \mathrm{N} \text { controls: } \mathrm{N} \text { content crop at harvest/total } \\
\text { of } \mathrm{N} \text { sources. } \\
\text { (ii) apparent nitrogen recovery for treatments with } \\
\text { fertilizer } \mathrm{N} \text {. }\end{array}$} \\
\hline
\end{tabular}

* $\mathrm{v}$ indicates variable value, depends on treatment.

$\dagger$ Net mineralization in Expt 3 was not measured but assumed to be equal to the rate measured in Expt 4.

\$ It was assumed that $50 \%$ of the total annual atmospheric deposition becomes available to the crop.

\section{Efficiency of nitrogen utilization}

The efficiency of utilization is the proportion of $\mathrm{N}$ from all sources that ends up in the zero- $\mathrm{N}$ controls, plus the apparent nitrogen recovery for fertilizer $\mathrm{N}$ (Table 2). The $\mathrm{N}$ utilization of the zero- $\mathrm{N}$ control, i.e. $\mathrm{e}_{\mathrm{s}}$ in Eqn (1), was 0.48 in Expt 3 and 0.42 in Expt 4. ANR, or $e_{a}$ in Eqn (2), ranged between 0.48 and 0.68 (Fig. 6). In Expt 3 ANR was higher with split applications than with a single dose and declined with increase in the total amount of $\mathrm{N}$ applied. In Expt 4 there were only small differences in ANR between the treatments.

\section{Assessment of nitrate leaching}

Figure 7 shows that the relationship between the amount of $\mathrm{Br}^{-}$, remaining in the top $60 \mathrm{~cm}$ of the soil, could be described as a linear function of the cumulative rainfall. Per mm rainfall $0.4 \%$ of the initial $\mathrm{Br}^{-}$moved out of the top $60 \mathrm{~cm}$. Such a regression is only an approximation of the $\mathrm{Br}^{-}$ movement because many factors affect the relationship, including changes in soil water content between samplings. Among samplings soil moisture content ranged between 8 and $12 \%$ (weight basis); for the given soil bulk density $\left(1.4 \mathrm{Mg} / \mathrm{m}^{3}\right)$ that difference represents $34 \mathrm{~mm}$ of soil water in the top $60 \mathrm{~cm}$. The main, qualitative, message of Fig. 7 is that, due to dispersion of the soil solutes, incidences of rainfall result in washing of some of the nitrate to soil layers below $60 \mathrm{~cm}$ depth.

The precipitation surplus amounted to $72 \mathrm{~mm}$ in the periods April III (day numbers 20-30 in April) and May I (day numbers 1-10) in 1992 (Fig. 8). However, this was before the first nitrogen dressing was applied and cannot have affected fertilizer-N 


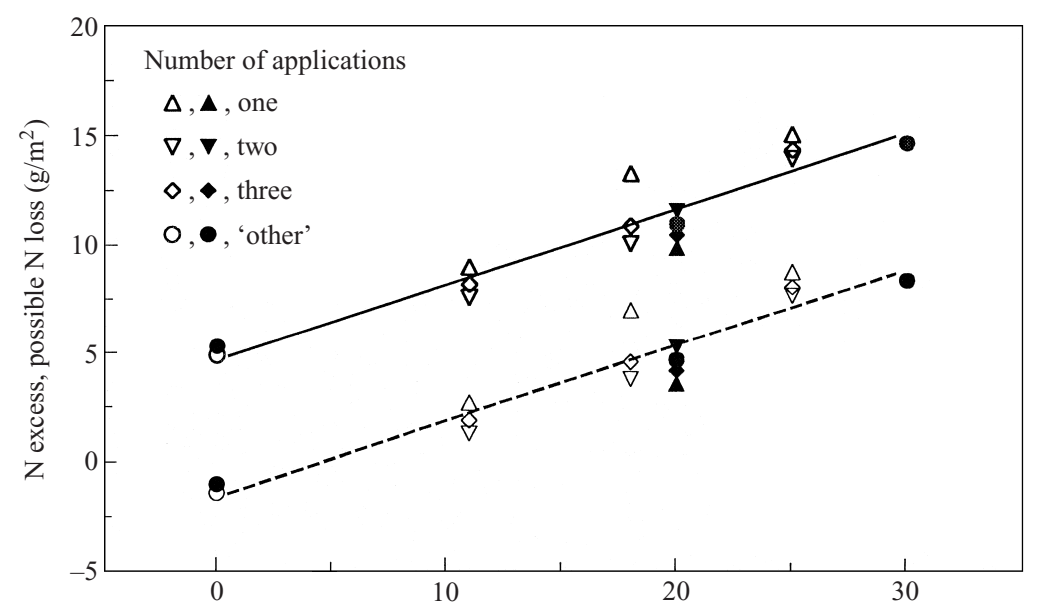

Fig. 5. $\mathrm{N}$ excess (solid line) and possible $\mathrm{N}$ loss (broken line) as functions of the total amount of $\mathrm{N}$ applied. $\mathrm{N}$ excess is defined in Table 2. Open symbols: Expt 3, solid symbols: Expt 4. The term 'other' for number of applications stands for the zero fertilizer $\mathrm{N}$ controls and the treatment given $20 \mathrm{~N} \mathrm{~g} / \mathrm{m}^{2}$ on the second application date $(\mathrm{N} 0+20)$ in Expt 4 and the high $\mathrm{N}$ control with $25 \mathrm{~g} / \mathrm{m}^{2}$ near planting and $5 \mathrm{~g} / \mathrm{m}^{2}$ on the second application date $(\mathrm{N} 25+5)$. The equation for $\mathrm{N}$ excess is $Y=4 \cdot 7$ (S.E. $1 \cdot 1)+0 \cdot 35($ S.E. $0 \cdot 03) X, r^{2}=0 \cdot 89$; for the possible loss it is: $-1 \cdot 6($ s.E. $1 \cdot 1)+0 \cdot 35$ (s.E. $\left.0 \cdot 03\right) X, r^{2}=0 \cdot 87$.

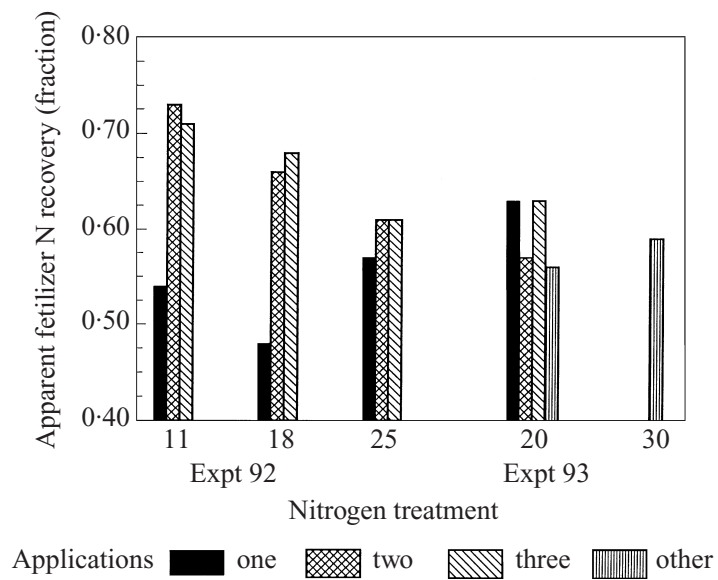

Fig. 6. Apparent fertilizer $\mathrm{N}$ recovery for each of the treatments. The term 'other' for applications designates the treatments $\mathrm{N} 0+20$ and $\mathrm{N} 25+5$ of Expt 4 (see legend to Fig. 5).

losses (actually, the first nitrogen application in Expt 3 was postponed because of these wet conditions). Initial soil mineral N (Table 1, Fig. 4a) was also determined after these rains. Downward movement of nitrate will have occurred from August II onwards if nitrate was present in the top soil. However, at and probably before 10 August (84 DAE) soil mineral N showed already low values (Fig. $4 a$ ). In Expt 4 there were no extended periods of precipitation surpluses or deficits. If nitrate was available, part of it will have moved out of the top $60 \mathrm{~cm}$ in July III, 1993. However, on 6 July (55 DAE) soil mineral $\mathrm{N}$ in the 0-60 $\mathrm{cm}$ layer had already declined to low values (maximally $5 \cdot 7 \mathrm{~g} / \mathrm{m}^{2}$ in treatment $\mathrm{N} 25+5$ ), implying that actual leaching losses, if occurring at all, would have been small.

\section{DISCUSSION}

The physiology of the crop limits the total period during which supplemental $\mathrm{N}$ can effectively be applied and limits its optimal distribution during that period. If nitrogen is deficient, the rate of leaf expansion is decreased (Biemond \& Vos 1992), resulting in smaller leaves. Since, for a given leaf age, the photosynthetic capacity (Vos \& van der Putten 


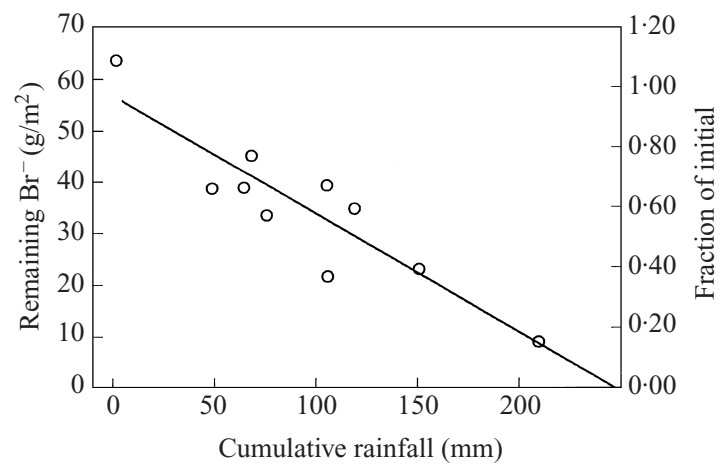

Fig. 7. The amount of $\mathrm{Br}^{-}$in the top $60 \mathrm{~cm}$ of the soil as a function of the cumulative rainfall between 14 September 1995 and 5 March 1996. Observations were made on the same field where Expts 3 and 4 had been done. Initially $58 \mathrm{~g} / \mathrm{m}^{2} \mathrm{Br}^{-}$was surface applied. The remaining absolute amount of $\mathrm{Br}^{-}$is on the left $Y$ axis; the fraction of the initial amount remaining is on the right $Y$ axis. The regression line is 57 (S.E. 4.2) -0.23 (S.E. 0.03) $X$, when expressed in absolute terms or $Y=0.98$ (S.E. $0.072)-0.004$ (s.E. 0.0007$) X$ as fractions.

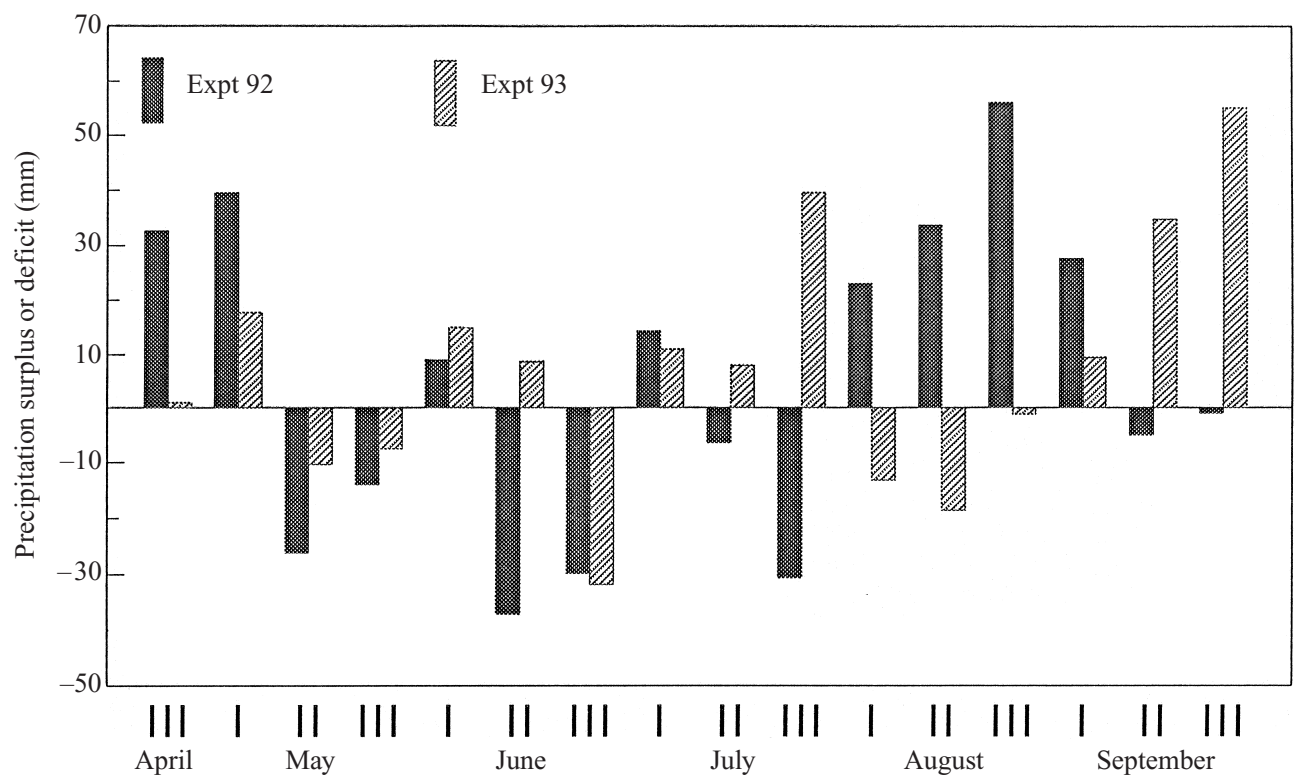

Fig. 8. Calculated precipitation surplus (positive values) or deficit (negative values) per period; periods I, II and III of a month count day numbers $1-10,11-20$ and the remaining part of the month, respectively.

1998) and radiation use efficiency (Millard \& Marshall 1986) are only marginally affected by nitrogen, smaller leaves in somewhat $\mathrm{N}$ deficient crops will affect the growth rate of the crop only if the fraction of light interception is reduced compared with non-deficient crops. Thus, the initial rate of $\mathrm{N}$ supply needs to be sufficient to avoid any depression in the rate of increase in the fraction of light interception. Although the pattern of uptake depends on the timing of the $\mathrm{N}$ applications (Figs $1 f$ and $2 f$ ), it was found in several studies that the bulk of the final amount of $\mathrm{N}$ is absorbed during the first half of the growing period
(Millard \& MacKerron 1986; Millard \& Marshall 1986; Duchenne et al. 1997). Internal relocation of $\mathrm{N}$ from haulms to tubers is a significant process during the second half of the growing period. If sufficient nitrogen can be accumulated during the first half of the growing period, there is little reason to extend repeated applications to later stages of growth, although capacity for uptake exists until late stages of growth (Vos \& Biemond 1992).

The general finding in these experiments, corroborating earlier reports (see Introduction), was that splitting the total nitrogen dose into a number of 
applications had no statistically significant effect on dry tuber yield. Although splitting the nitrogen dose showed some advantage in the utilization of nitrogen in Expts 3 and 4 (Fig. 6), the gain was not large (Westermann et al. 1988). More striking was that data points of the $\mathrm{N}$ excess (i.e. that part of the $\mathrm{N}$ budget that remained unaccounted for) of both experiments fell on one line when plotted against the amount of $\mathrm{N}$ applied, implying that, under the conditions of the experiments, the total supply, rather than the distribution of applications, determined the efficiency of utilization and its complement, the possible loss of $\mathrm{N}$.

The observed nitrogen response, in terms of apparent recovery, and hence also in terms of (potential) losses, is in line with data from 98 potato fertilizer trials described by Neeteson (1989). Therefore, the numerical values of the parameters $e_{\mathrm{s}}$ in Eqn (1) and $e_{\mathrm{a}}$ in Eqn (2) (Fig. 5) can be used in practice as (initial) estimates to make calculations on the nitrogen requirement of potato on sandy soils. The coefficient $e_{\mathrm{a}}$ (or ANR), however, is not a constant; it generally declines with increase in level of $\mathrm{N}$ supply (Neeteson et al. 1987; Greenwood et al. 1992).

In the current experiments measures were taken to prevent any stress. Under such conditions little benefit, in terms of yield and $\mathrm{N}$ utilization, was gained from splitting a particular amount of fertilizer $\mathrm{N}$ in comparison with a single dressing. In comparison with a single dose, splitting $\mathrm{N}$ results in a higher yield only when nitrogen is lost early in the season and not replaced in the system with one application at planting. Proper management of nitrogen, rather than improving yield, justifies split applications, because that system provides the opportunities to better adapt the application of $\mathrm{N}$ to the crop's need as it develops during the season, whilst preventing losses early in the season. The conclusion from this study is that the time window for adjusting $\mathrm{N}$ application to estimated requirements extends to (at least) 60 days after emergence. The period before emergence can be added to the total period in which decisions on $\mathrm{N}$ application can be made.

The current results imply that spending money on soil analysis in early spring to guide $\mathrm{N}$ application is not the best option. An alternative is to apply a starter amount of $\mathrm{N}$, perhaps banded in the potato hill, and postpone the decision on the total amount of $\mathrm{N}$ needed to the period June-early July.

Split $\mathrm{N}$ application has disadvantages. Costs are involved in each extra $\mathrm{N}$ application. In the absence of irrigation, granular fertilizers may sit ineffectively on a dry soil surface until the next rainfall. During prolonged drought, the additional $\mathrm{N}$ may be taken up too late to be effective. If one wants the additional $\mathrm{N}$ to be available to the crop at $60 \mathrm{DAE}$ at the latest, one can calculate how many days earlier the last $\mathrm{N}$ application needs to be applied if one wants, for instance, at least $10 \mathrm{~mm}$ rainfall to occur with a probability of $90 \%$ between the date of application and $60 \mathrm{DAE}$ (the earlier the last $\mathrm{N}$ is applied, the higher the chance of rain before 60 DAE). The dependency of rain to wash $\mathrm{N}$ into the soil does not exist for foliar feeding of liquid fertilizer. That way of applying $\mathrm{N}$, perhaps in combination with fungicide application, could turn out to be useful (Goffart et al. 1999).

Thanks are due to the former students M. Bom, P. Huisman, K. Kramer, S. Liberatori, S. van de Weerd and $\mathrm{B}$. de Witte for their contribution to the experiments, to the Department's experimental services UNIFARM, and to H. Halm, P. E. L. van der Putten and $J$. van der Laan for assistance with the chemical analyses.

\section{REFERENCES}

Bachthaler, G., Strass, F., Stricker, H. W. \& Hunnius, W. (1973). Rate and distribution of nitrogen fertilizer for potatoes in the Münchner Schotterebene (in German). Bayerisches Landwirtschaftliches Jahrbuch 50, 56-69.

BIEMOND, H. \& Vos, J. (1992). Effects of nitrogen on the development and growth of the potato plant. 2. The partitioning of dry matter, nitrogen and nitrate. Annals of Botany 70, 37-45.

De Smed, F., Wanters, F. \& Sevilla, J. (1986). Tracer movement through unsaturated sand. Journal of $\mathrm{Hy}$ drology 85, 169-181.

Duchenne, T., Machet, J. M. \& Martin, M. (1997). Potatoes. In Diagnosis of the Nitrogen Status in Crops (Ed. G. Lemaire), pp. 119-130. Berlin: Springer-Verlag.

FEDDES, R. A. (1987). Crop factors in relation to Makkink reference-crop evapotranspiration. In Evaporation and Weather (Ed. J. C. Hooghart), Proceedings and Information No. 39, pp. 33-45. The Hague: TNO-Committee on Hydrological Research.
Goffart, J.-P., Olivier, M. \& Destain, J. P. (1999). Interest of foliar-applied urea vs. ammonium nitrate as supplemental N-dressing for the potato crop. In $14^{\text {th }}$ Triennial Conference of the European Association for Potato Research-Abstracts of Conference Papers, Posters and Demonstrations, Sorrento, Italy, May 2-7, 1999, pp. 464-465. Sorrento: Assessorato Agricoltura Regione Campania.

Greenwood, D. J., Neeteson, J. J., Draycott, A., Wijnen, G. \& Stone, D. A. (1992). Measurement and simulation of the effects of $\mathrm{N}$-fertilizer on growth, plant composition and distribution of soil mineral-N in nationwide onion experiments. Fertilizer Research 31, 305-318.

HAVERKORT, A. J. \& VAN DE WAART, M. (1994). Yield and leaf nitrate concentration of starch potato on sandy humic soils supplied with varying amounts of starter and supplemental nitrogen fertilizer. European Journal of Agronomy 3, 29-41.

Houba, V. J. G., Novozamsky, I., Hujubregts, A. W. M. \& 
VAN DER LEE, J. J. (1986). Comparison of soil extractions with $0.01 \mathrm{M} \mathrm{CaCl}$, by EUF and some conventional extraction procedures. Plant and Soil 96, 433- 437.

Millard, P. \& MacKerron, D. K. L. (1986). The effects of nitrogen application on growth and nitrogen distribution within the potato canopy. Annals of Applied Biology 109, 427-437.

Millard, P. \& Marshall, B. (1986). Growth, nitrogen uptake and partitioning within the potato (Solanum tuberosum L.) crop, in relation to nitrogen application. Journal of Agricultural Science, Cambridge 107, 421-429.

NeEteson, J. J. (1989). Evaluation of the performance of three advisory methods for nitrogen fertilization of sugar beet and potatoes. Netherlands Journal of Agricultural Science 37, 143-155.

Neeteson, J. J., Greenwood, D. J. \& Draycott, A. (1987). A dynamic model to predict yield and optimum nitrogen fertilizer application rate for potatoes. Proceedings 262. London: The Fertiliser Society.

Novozamsky, I., van EcK, R., van SchouwenburG, J. C. \& Walinga, I. (1974). Total nitrogen determination in plant material by means of the indophenol blue method. Netherlands Journal of Agricultural Science 22, 3-5.

Novozamsky, I., Houba, V. J. G., van EcK, R. \& van VARK, W. (1983). A novel digestion technique for multielement plant analysis. Communications in Soil Science and Plant Analysis 14, 239-249.

Porter, G. A. \& Sisson J. A. (1993). Yield, market quality and petiole nitrate concentration of non-irrigated Russet Burbank and Shepody potatoes in response to sidedressed nitrogen. American Potato Journal 70, 101-116.

Raison, R. J., Connell, M. J. \& KhannA, P. K. (1987). Methodology for studying fluxes of soil mineral-N in situ. Soil Biology and Biochemistry 5, 521-530.

Vos, J. (1996). Input and offtake of nitrogen, phosphorus and potassium in cropping systems with potato as a main crop and sugar beet and spring wheat as subsidiary crops. European Journal of Agronomy 5, 105-114.

Vos, J. (1997). The nitrogen response of potato (Solanum tuberosum L.) in the field: nitrogen uptake and yield, harvest index and nitrogen concentration. Potato Research 40, 237-248.

Vos, J. (1999). Potato. In Crop Yield-Physiology and Processes (Eds D. L. Smith \& C. Hamel), pp. 333-354. Berlin: Springer-Verlag.

Vos, J. \& Biemond, H. (1992). Effects of nitrogen on the development and growth of the potato plant. 1. Leaf appearance, expansion growth, life spans of leaves and stem branching. Annals of Botany 70, 27-35.

Vos, J. \& VAN DER PUTTEN, P. E. L. (1998). Effect of nitrogen supply on leaf growth, leaf nitrogen economy and photosynthetic capacity in potato. Field Crops Research 59, 63-72.

Westermann, D. T., Kleinkopf G. E. \& Porter L. K. (1988). Nitrogen fertilizer efficiencies on potatoes. American Potato Journal 65, 377-386. 